\title{
WestVirginiaUniversity.
}

Department of Economics

Working Paper Series

\section{Charity and Public Libraries: Does Government Funding Crowd-out Donations?}

Amir Borges Ferreira Neto

Working Paper No. 17-02

This paper can be found at the College of Business and Economics Working Paper Series homepage: 


\title{
Charity and Public Libraries: Does Government Funding Crowd-out Donations?
}

\author{
Amir Borges Ferreira Neto \\ Department of Economics \\ College of Business and Economics \\ West Virginia University \\ 1601 University Ave., PO Box 6025 \\ Morgantown, WV 26506-6825 \\ Email: amneto@mix.wvu.edu
}

\begin{abstract}
There are over 9,000 public libraries in the United States servicing more than 1.5 billion people and raising over $\$ 11.5$ billion dollars in revenue with approximately $8 \%$ of this total coming from donations. This paper analyzes the determinants of donations to public libraries testing the following hypothesis: is there a crowding-out effect from government funding of public libraries? I address this issue by looking at novel data, the Public Library Survey, and use panel from 2000 to 2013. The results suggest a crowding in effect in all levels of government: 4 to 6 cents in local government, 20 to 23 cents in state government and 75 cents to 1 dollar and 33 cents in federal government. Also, the government expenditure has an inverted U shape.
\end{abstract}

Keywords: Charity, Crowd-out, Donation, Government Spending, Public Libraries

JEL Codes: H41, Z11 


\section{Introduction}

Recent pressure to reduce public budgets have been affecting public libraries all across the country. There are, for example, reports of budget cuts in libraries in New York, Florida, Nebraska, Georgia, Michigan and Oregon ${ }^{1}$ (Blau 2011 and Warbuton 2013). These budget cuts may have a significant negative effect on public libraries, as over 90 percent of their revenues, which accounted for $\$ 11.5$ billion dollars in 2012, comes from governments (IMLS, 2013). Thus, such government budget cuts make other components of a library’s revenue, namely, donations from private individuals and grants, relatively more important.

In the United States there are 9,082 public libraries, which correspond to approximately 8 percent of all libraries in the country (ALA, 2015). The Institute of Museums and Library Services (IMLS, 2013) reported that these public libraries accounted for 1.5 billion in-person visits in 2012. By looking at the libraries' revenue and in-person visits numbers alone, it is possible to understand the importance of public libraries in a public finance perspective. However, public libraries also provide important services that can be overlooked sometimes, such as Internet access and job searching, for example (ALA 2010 and iPAC 2016). Moreover, Bhatt (2010) shows that visiting a library increases the time children enrolled in school spend at home reading. In turn, this positively impacts their homework completion rates.

Therefore, given the importance of public libraries as a service versus the losses on revenue due to pressure on budget cuts, this paper focuses on sources of revenue to public libraries. More specifically, this paper aims to evaluate the donations to public libraries at an institutional level, and test the hypothesis of donations being crowded-out by government

\footnotetext{
1 Smith (2015), Kelley (2015), Davis (2015), Stepleton (2015), Woods (2015), and Cleaver (2015) also present reports on library budget cuts. A quick search on Google News can present the interested reader with other recent examples.
} 
expenditure. Furthermore, I consider another important feature that may affect donations to libraries, namely, the historic aspects of charity and donations. Hence, I contribute to the growing empirical literature on charitable donations, focusing specifically on public libraries. Moreover, few studies consider the role played by different locations (i.e., the historic aspects), except for the differences in tax exemption.

With regard to historical aspects, charity in the United States, especially during Colonial times, was influenced by England. As an example, Americans followed ideas of entrusting some charity responsibilities to local authorities and private agents (Katz 2006). After the Revolutionary War, however, the environment for charity support was hostile all across the country, except for New England. After several actions from the Supreme Court in the 19th century, charitable activity thrived in the Northeast and upper Midwest. However, these activities did not perform as well in other regions of the country (Katz 2006). Although demographic changes have occurred since then, most of the institutional framework remains similar as do regional traditions and characteristics. This suggests that regional characteristics may still play a role in donation behavior.

Katz (2006) provides a brief discussion about the American interest in giving. The author concludes that "their instinct to imagine and support the non-profit engines of human betterment derive from the original Carnegie-Rockefeller tradition" (Katz 2006, 1316); in other words, an altruistic behavior. Andreoni (1990) states that people are not indifferent between who makes a donation: themselves or others. Thus, when taking altruism into account, the public goods model provides more intuitive results. Examples of such results are that the distribution of income matters when it comes to donations, governments do not crowd out private provision, and subsidies can have the desired effect on donations (Andreoni 1990). 
Nevertheless, there are several studies that analyze how different institutions or features impact charity giving. Gruber and Hungerman (2007) and Khanna et al. (1995), for instance, focus on religion; Beranek et al. (2010), Bakija et al. (2003) and Peloza and Steel (2005) concentrate on tax systems; Borgonovi (2006), Steinberg (1991), Brooks (2003), Simmons and Emanuele (2004), Okten and Weisbrod (2000) and Payne (1998) study the impact of government funding on private donation.

This paper's interest resides primarily in examining the role of government on private donation behavior. Some of the results found in the literature ${ }^{2}$ are as follows: Simmons and Emanuele (2004) find a negative relation between government spending and donations. Payne’s (1998) study of shelters between 1982 and 1992 finds evidence of crowding out when controlling for possible endogeneity of government grants. Okten and Weisbrod (2000) analyze Internal Revenue Service data for individual non-profits between 1982 and 1994 and find that: (i) the price of donation has a negative effect on donations, (ii) the government's grant and own programs do not crowd-out private donations, and (iii) surprisingly, there is a positive effect of government grants and own program sales in donations in most of the industries analyzed. Brooks (2003) finds a neutral effect of public funding on total donation. Borgonovi (2006) finds evidence of crowd-out effects of government funding on private donation to theaters.

To address the question of how government funding affects donations, I use the Public Library Survey. This survey can be considered the census of public libraries because it has a rate of response of over 98 percent. I restrict my sample to the years of 2000 to 2013 and evaluate the donations to individual public libraries. To test the hypothesis that government crowds-out

\footnotetext{
2 Borgonovi (2006) provides an extensive review of the literature on government effects on do- nations: crowdingout and crowding-in. Steinberg (1991) also provides an extensive review of the crowd-out literature and raise important questions and issues to improve estimations.
} 
donation, I regress the amount of revenue from the different levels of governments on the revenue from donation. I differentiate the levels of government because Borgonovi (2006) argues that the level of donations and support are relevant. Also, I follow Brooks (2003) and Borgonovi (2006) and specify a quadratic relation for the government revenues. Moreover, I control

donations for library features and demographics at a state level. Finally, the panel structure of the data allows me to control for fixed effects at a county and state level. The main results show a positive correlation between donations and government expenditure, hinting at a crowding-in effect. The estimated upper bound is between 4 cents to 1.3 dollars, depending on the level of government. Furthermore, regional differences seem to be important but not determinant when it comes to charitable giving.

The remainder of the paper is structured as follows: Section 2 describes the intuitive model and the empirical approach to estimate the crowding effect; Section 3 presents the Public Library Survey data and its descriptive statistics; Section 4 discusses the results; and Section 5 concludes, laying out some implications of study.

\section{Model and Empirical Approach}

\subsection{Model}

Individuals try to maximize their utility when donating to a charity. In an aggregate level, it is possible to write

Donation $=f(G, X, R)$

where, $G$ is the amount of government revenues, $X$ is the characteristics of the donors, and $R$ is characteristics of the region. 
Borgonovi (2006) argues that the interdependent utility model is the base for the charitable donation literature (Abrams and Schmitz, 1984; Reece, 1979; Andreoni and Scholz, 1998; Russel, 2008). This model can either capture a crowd-in or crowd-out effect, thus it is not restrictive. However, the crowd-out effect is expected to have a quadratic form in an inverted U shape (Brooks, 2003). Therefore,

$\frac{\partial \text { Donation }}{\partial G}=\frac{\partial f(.)}{\partial G} \gtrless 0 ; \frac{\partial^{2} \text { Donation }}{\partial G^{2}}<0$

Katz (2006) points out that different regions in the United States followed different traditions with respect to charitable donations. These activities thrived in the Northeast and upper Midwest, but not in the South. Moreover, tax $(\tau)$ systems in each state differ from each other, what make incentives different for private donors, because taxes would represent the price of giving (Clotfelter 1980, Andeoni 1989, Brown and Lankford 1992, Feldstein and Taylor 1976). Hence,

$\frac{\partial \text { Donation }}{\partial R}=\frac{\partial f(.)}{\partial R} \gtrless 0 ; \frac{\partial X}{\partial \tau}<0$

Another important feature of the donation literature (Andreoni 1995, Harbaugh 1998, Menges et al. 2005, Crumpler and Grossman 2008) is the warm-glow effect. According to the warm-glow literature, donors gain utility when donating, but they are not purely altruistic nor purely egotistic. Crumpler and Grossman (2008) argue that no study has isolated this effect until the present time.

One interesting aspect of donations to institutions is the classification mechanism they use, which can be tightly related to the warm-glow hypothesis. Harbaugh (1998) stresses that 
institutions usually publicize donors by sorting them into different categories by the amount donated and publicizing their names on its walls. Assume donors care about the institution they donate to, so their marginal utility from donating is positive. Also, assume donors want to increase the warm-glow effect by being recognized by their donations to one specific category. Therefore, two mechanisms may be in place. On the one hand, donors may focus on institutions with lots of visibility in order to have their name viewed by the largest number of people as possible. On the other hand, donors may focus on those institutions that really need the money, thus having more recognition and appreciation for their contribution. Since I cannot observe donors' behavior directly nor the number of donations individually, but only the total amount of donations to each library, it is not possible to properly capture the warm-glow effect for the donations.

\subsection{Empirical Approach}

Differently from most studies on charitable donations, the Public Library Survey (PLS) dataset does not have observations on donors, but instead on public libraries. Hence, I evaluate the crowding effect from government spending at an institutional level, with a similar framework of the one used by Borgonovi (2006). The PLS is a rich dataset containing over 50 variables on the features of public libraries across the United States.

Following the intuitive model presented above, I estimate the following equation:

$$
\begin{aligned}
& \text { Donation }_{n c s t}=\alpha+\beta_{1} \text { LOCGVT }_{n c s t}+\beta_{2} \text { STGVT }_{n c s t}+\beta_{3} \text { FEDGVT }_{n c s t}+\boldsymbol{X}_{n c s t} \gamma+\boldsymbol{Z}_{s t} \delta+ \\
& \mu_{n}+\eta_{c}+v_{s}+\lambda_{t}+\varepsilon_{n c s t}
\end{aligned}
$$


where, Donation $n_{\text {ncst }}$ is the amount donated to library $n$, in county $c$, in state $s$, in year $t$; LOCGVT is the amount of revenues from local government; STGVT is the amount of revenues from state government; FEDGVT is the amount of revenues from federal government; $\boldsymbol{X}_{n c s t}$ are the characteristics of the library $n ; \boldsymbol{Z}_{s t}$ are the demographic characteristics of the state; $\mu_{n}, \eta_{c}$, and $v_{s}$ are non-observable characteristics of the library, county, and state, respectively; $\lambda_{t}$ is the time fixed effect; and $\varepsilon_{n c s t}$ is the error term.

Unfortunately, I cannot observe donations per se. I can, however, observe other types of revenues, namely, fees, grants and donations. It is expected that the largest share of these “other revenues” are donations, as fees and fines would represent a smaller value. Also, I follow Borgonovi (2006) who argues that it is important to differentiate between the levels of government when analyzing crowding effect.

As discussed in the previous sections, the regional characteristics may influence the level of donation. The vector $\boldsymbol{Z}_{s t}$ controls for observable variables such as average age and the percentages of women, white and black people, married couples, immigrants, people with high school degrees and bachelor degrees, unemployed people. The $\eta_{c}$ and $v_{s}$ terms capture nonobservable characteristics, including tax. Also, I created three other dummy variables assuming value of one if the library is either in the New England, Mideast or Great Lakes regions in order to control for the regions highlighted by Katz (2006).

The variables in the $\boldsymbol{X}_{n c s t}$ vector are: attendance, kids' programs attendance, book collection, number of employees, number of hours opened, number of computers with access to the Internet for the general public and a dummy variable if the library had any contemporaneous capital outlay. 


\section{Data}

The Public Libraries Survey (PLS) has been collected annually since 1988 and covers all 50 states, the District of Columbia, and outlying territories. It provides statistics for almost every public library in the United States (IMLS 2013). As the PLS has over a 98 percent response rate, it can be considered a census of public libraries in the United States.

According to the IMLS website, these data are not attached to any specific program, and it is not mandatory. Therefore, there are no incentives to over- or under-report the values in the survey, which makes this data less subject to biased reporting. The PLS survey provides data for each library covering several features, such as: location (full address and geocodes), state characteristics (population serviced), and administrative data (number of staff, revenues by source, costs, collection expenditures, collection, circulation, attendance, among others). Since the early 2000s, with the advance of the Internet and its access, there has been a shift in the function of libraries and their perception from the general public; therefore, I restrict my analysis to the years of 2000 to 2013.

The data on the characteristics of the states comes from a sample of the Integrated Public Use Microdata Series - Current Population Survey (IPUMS-CPS, 2015) provided by the Minnesota Population Center. The sample is at an individual level, and it was aggregated to state level averages using weights provided by the IPUMS-CPS. Table 1 presents the description of the variables and Table 2 presents the descriptive statistics of both datasets used in this paper.

$<$ TABLE 1>

$<$ TABLE 2>

I use the IPUMS-CPS variable for deflation and I drop from my sample the 30 observations considered outliers; i.e., libraries with more than $\$ 1.4$ million dollars in real terms. 
These observations are described in Table 3. It is noteworthy that from the 30 dropped observations, 14 of them are the New York Public Library. Figure 1 shows donation versus each level of government expenditure with (above) and without (below) outliers.

$<$ TABLE 3>

$<$ FIGURE 1>

Another important feature of the data is the difference in the schedule of the reports. Table 4 presents schedule differences between states. To control for this, I included a dummy variable in the OLS regression and in the county fixed-effects model; however, because of collinearity, this dummy is dropped on the state fixed-effects model, which would also capture this difference.

$<$ TABLE 4>

\section{Results}

Following the literature presented in Section 1, I estimate the model presented in Section 2, and focus on the contribution of government as an explanation for donations to libraries. Besides government revenues, I include state socio-demographics and libraries characteristics. Table 5 presents the OLS regression models. Model (1) is the Pooled OLS and models (2) to (4) have some type of fixed effect - year, county, state and library. In the following paragraphs, I discuss the results focusing on the two issues presented in the previous sections: government, and regional differences.

Following Borgonovi (2006), the data structure of the Public Library Survey allows me to differentiate the government expenditure on its several levels - local, state and federal. The author shows that for theaters this distinction is significant, and from Table 5 the same holds for 
public libraries. In all the models regressed, there is a positive correlation between donations and government spending, suggesting a crowding-in effect of government expenditure on every level.

In the POLS regression - Model (1) - for every dollar spent by local, state and federal governments, donations would increase by 2.3 cents, 19 cents and 60 cents, respectively. The results change when introducing library fixed effect. In Model (4), the preferred model, local government expenditure is not statistically significant, state government expenditure would decrease donation by 6.6 cents per dollar spent, and federal government would increase it by 24 cents.

With regard to the regional effects, there are some mixed results. At first, there is a difference in the estimated coefficients when introducing the different regional fixed effects. Moreover, by analyzing Models (1) to (2), being in the Mideast and New England seems to increase donations while being in the Great Lakes seems to decrease donations when controlling for county and year fix effect. Hence, I do not have a clear picture if the historical features described by Katz (2006) are still in place. On the other hand, the results imply that regional unobservable effects affect donations to libraries.

The number of observations in Table 5 is smaller than in the next set of tables because of missing data on the right-hand side variables. Two of these variables included in Table 5 are a dummy if the library is run by the school district and a dummy if the library is run by a nonprofit. Fischel (2010) argues that there should be congruence between city and school district boundaries, resulting in synchronization between public library programs and school curricula. Also, if parents were to donate to a public library, having the library run by the school district would be one argument in favor of donations. However, the results show no statistical 
significance for this dummy variable. On the other hand, being run by a non-profit has a positive statistically significant result in the OLS model and county-year fixed effect model, but a negative sign in the library-county-state-year fixed effect model. Hence, when taking nonobservable characteristics of libraries into account, the results suggests not-for-profit libraries receive fewer donations.

\section{$<$ TABLE 5 $>$}

Two sources of endogeneity may be present in the models regressed: the variable that measures donation and the reporting itself. The latter is less likely to be present. As explained in Section 3, there is no incentive to over- or under-report the revenue from donations or government. As for the former, I cannot measure donation per se, but actually a mix of fees, grants and donations. Nevertheless, fees and grants are not expected to be as high as private donations. Moreover, I expect grants not to be correlated to donations and the amount of library fees to be random across libraries. Also, it is important to stress that my data is left truncated, as there can be no negative donation or contribution from government.

The left-truncated characteristic of the data makes the results presented in Table 5 biased and not consistent. Table 6 presents the results with Tobit estimations. I estimated four models: in model (1) there are only government revenues in the right-hand side, in model (2) there are some library and state control variables, and there is no fixed effect in either of these two models. Model (3) equals model (2) with state fixed effect and model (4) equals model (1) with state and year fixed effect.

<TABLE 6> 
All four Tobit models have similar results between them. The results hint at a crowding-in effect in donations and an inverted U shape curve feature at every level of government expenditure. These results suggest local governments crowd-in 6 cents for every dollar spent, state government brings an additional 23 cents, while federal government increases donations by 1 dollar and 33 cents for every dollar spent.

The crowding-in effect when analyzing a cultural sector is not new in the literature. For example, Paqué (1982) finds evidence of crowding-in effect in art activities in Germany; Okten and Weisbrod (2000) find crowding-in effect in libraries, research and higher education; Smith (2003) finds crowding-in for dance companies; and Borgonovi (2006) finds crowding-in effect on expenditure of local government in theaters.

Borgonovi (2006) argues that the crowding-in effect can be explained by a signaling mechanism. Donors would consider libraries that receive government funding as ones with a better reputation, thus more secure in which to invest. Another argument provided by the author is the independent utility framework, "the additional support that public grants provide at low levels of total donative revenues (public and private) allows recipients to expand their activities and undertake new and/or better projects" (Borgonovi 2006, 432).

According to Borgonovi (2006) and Brooks (2003), I should find an inverse U shape curve in the government expenditure. In both Table 5 and Table 6, the results imply such a curve in government expenditure. It is important to stress again that one of the caveats of this paper is not being able to disentangle donations from grants and fees.

\subsection{Robustness Check}


In this subsection I present some other models estimated as robustness checks. First, I present models with per capita values, using the legal service area as a catchment area. This is an important exercise because not considering a catchment area can lead to overestimated results. Then, I present the results for all the data; that is, I include the 30 outliers removed earlier as a sensitivity analysis.

Although I controlled for population in the previous estimated equations, this does not capture the catchment area of each library. Therefore, I re-estimated all models in Table 5 and models (1) and (4) in Table 6. Thus, Table 7 presents the per capita estimation of the POLS model and Fixed Effect models, and Table 8 presents the re-estimated Tobit models.

The estimated per capita models (Table 7) present the same features as the Tobit models in Table 6: there is a positive correlation between donation and all levels of government and an inverted $\mathrm{U}$ shape for local and federal government. It is interesting to note that the coefficients have a slight decrease such that the local government would bring around 2 cents, state government 3 cents and federal government 1 dollar and 25 cents. The regional dummies, although statistically significant, are close to zero. As for Table 8, the Tobit models also have similar results to those of Table 6, but with smaller coefficients. These results suggest local governments crowd in 4 cents for every additional dollar spent, local governments brings in 20 cents, and federal governments increase donations by 73 cents.

$<$ TABLE 7>

$<$ TABLE 8>

Lastly, it is important to make a sensitivity analysis and estimate the models including the outliers removed from previous analysis. Table 9 presents the POLS, Fixed Effects and Tobit 
results using the complete dataset. Focusing on the Tobit model with fixed effects (6), the results suggest that there is a crowd-out effect from local government of 5 cents and a crowd-in effect from state government (42 cents) and federal government (3 dollars and 30 cents). The inverted $\mathrm{U}$ shape is only found for the state and federal government expenditures. Although these results only corroborate the results for state and federal government, as shown in Figure 1, the outliers are most concerning in the relationship between local government and donation. Therefore, I believe the results presented in Table 6 are more accurate than those in Table 9.

\section{Conclusion and Implications}

The goal of this paper is to evaluate the crowding effect of government expenditure on private donations to public libraries. To determine if government crowds-out donations, I used a panel of public libraries from 2000 to 2013 from the Public Library Survey. This dataset allowed me to identify revenues from donation and from the different levels of government - local, state and federal - and several features of each library. Also, I used data from the IPUMS-CPS, provided by the Minnesota Population Center, to control for state socio-demographic characteristics.

The results show a positive correlation between donation and government spending in every level, which points to a possible crowding-in effect. That is, every dollar spent by the government would bring some extra amount of money to the libraries. More specifically, the

results suggest local government would bring an extra 4 to 6 cents in donation, state government 20 to 23 cents and the federal government 73 cents to 1 dollar and 33 cents per dollar spent. As do Borgonovi (2006) and Brooks (2003), I also find an inverted U shape relation between government expenditure and donation. 
The results in the regional difference due to historic features described by Katz (2006) were not statistically significant or close to zero, hinting that these regions are not different from other U.S. regions. This provides some evidence that there has been some homogenization in terms of donation, at least to public libraries.

There are several implications from the results presented above. First, the results are another empirical contribution to the crowding effect of government expenditure. As well as other cultural types of activities, such as those analyzed in Paqué (1982), Okten and Weisbrod (2000), Smith (2003), and Borgonovi (2006), government revenues are correlated with more donation. In this particular case, the results imply government crowd in donation in every level local, state and federal. This would also corroborate the interpretation from Borgonovi (2006) in which donors use government funding as a signaling mechanism.

Secondly, as a result of the crowd-in effect, the cuts on government budgets to public libraries would mean they are worse than anticipated by policy-makers. For once, there is no guarantee that any level of government would compensate the loss in revenues from another level of government. Moreover, the results indicate that libraries whose revenues are cut would also lose money from donation as well, because donors would have a different perception due to the signaling mechanism.

Lastly, it is important to describe some consequences of these results for public policies. According to IMLS (2013), 91.8 percent of library revenues come from government; 84.4 percent are local, 6.9 percent are state and 0.5 percent is federal. This breakdown helps to shed light on the reason why every dollar from state and federal governments would bring more dollars from donation. However, it is clear that the biggest providers are local governments. 
Even with the extra amount of dollars that state and federal levels can bring, this extra amount would not suffice to cover cuts from local governments, at least not in an aggregate level.

Therefore, policy-makers should be cautious when cutting funds from public entities, especially from cultural-type entities such as public libraries because: (i) there seems to be an indirect budget effect that could further decrease revenues due to the suggested crowd-in effect; (ii) there might not be a substitution allowed in donation, i.e., donors could not reallocate a donation to a library into another public provided service, which could place more pressure on local governments; (iii) the direct cuts may force public libraries to close, which can have negative externalities, for instance, less access to the Internet and to jobs (ALA 2010 and iPAC 2016), a negative impact on education (Bhatt, 2010), and less tax-revenue if people value living close to libraries (Sheppard, 2010), among others.

Some of the caveats of this paper are the donation measure and level of observation. For the former, I cannot disentangle donation from grants and fees; therefore, I cannot conclude there is a casual effect between donation and government funding. At most, the results show they have a positive correlation between them. The ideal dataset would enable me to observe the characteristics of donors and the institutions to which they donate. Hence, I would be able to have better measurements to test the warm-glow hypothesis and to understand the relationship between donation and government expenditure. However, I must highlight that this does not invalidate this work, which still provides interesting results using novel data to analyze the determinants of donation.

\section{References}

Aabø, S. and Strand, J. (2004). Public library valuation, nonuse values, and altruistic motivations. Library and Information Science Research, 26:351-372.

Abrams, B. A. and Schmitz, M. D. (1984). The crowding-out effect of governmental transfers on private charitable contributions: Cross-section evidence. National Tax Journal, 37(4):563-568. 
American Library Association - ALA (2010).

http://www.ala.org/research/sites/ala.org.research/files/content/initiatives/plftas/issuesbriefs/brief _jobs_july.pdf. Accessed on June 10, 2015.

American Library Association - ALA (2015).

http://www.ala.org/tools/libfactsheets/alalibraryfactsheet01. Accessed on September 20, 2015.

Andreoni, J. (1989). Giving with impure altruism: Applications to charity and ricar- dian equivalence. Journal of Political Economy, 97(6):1447-1458.

Andreoni, J. (1990). Impure altruism and donations to public goods: A theory of warm-glow giving. The Economic Journal, 100:464-477.

Andreoni, J. (1995). Warm-glow versus cold-prickle: The effects of positive and nega- tive framing on cooperation in experiments. The Quarterly Journal of Economics, 110(1):1-21.

Andreoni, J. and Scholz, J. K. (1998). An econometric analysis of charitable giving with interdependent preferences. Economic Inquiry, 36(3):410-428.

Ballotpedia (2016). www.ballotpedia.org. Accessed on May 17, 2016.

Bakija, J. M., Gale, W. G., and Slemrod, J. B. (2003). Charitable bequests and taxes on inheritances and estates: Aggregate evidence from across states and time. The American Economic Review, 93(2):366-370.

Beranek, W., Kamerschen, D. R., and Timberlake, R. H. (2010). Charitable donations and the estate tax: A tale of two hypotheses. American Journal of Economics and Sociology, 69(3):1054-1078.

Bhatt, R. (2010). The impact of public library use on reading, television, and aca- demic outcomes. Journal of Urban Economics, 68(2):148 - 166.

Blau, R. (2011). Funding cuts closing book on all 62 branches in queens li- brary. http://www.nydailynews.com/new-york/queens/funding-cuts-closing-book- 62-branches-queenslibrary-article-1.141568.

Borgonovi, F. (2006). Do public grants to American theatres crowd-out private donations? Public Choice, 126(3/4):429-451.

Brooks, A. C. (2003). Do government subsidies to nonprofits crowd out donations or donors? Public Finance Review, 31(2):166-179.

Brown, E. and Lankford, H. (1992). Gifts of money and gifts of time estimating the effects of tax prices and available time. Journal of Public Economics, 47(3):321 - 341.

Cleaver, J. (2015). New hartford library grapples with budget cuts.

http://www.uticaod.com/article/20151117/NEWS/151119446.

Clotfelter, C. T. (1980). Tax incentives and charitable giving: evidence from a panel of taxpayers. Journal of Public Economics, 13(3):319 - 340.

Crumpler, H. and Grossman, P. J. (2008). An experimental test of warm glow giving. Journal of Public Economics, 92(5-6):1011 - 1021.

Davis, A. (2015). Looming crisis: Several local libraries preparing for cuts if state budget isn't passed. http://www.bradfordera.com/news/looming-crisis- several-local-libraries-preparing-for- 
cuts-if-state/article_15ebe634-9896-11e5-ae85- f30b1c870a7f.html.

Feldstein, M. and Taylor, A. (1976). The income tax and charitable contributions. Econometrica, 44(6):1201-1222.

Fischel, W. A. (2010). The congruence of american school districts with other local government boundaries: A google-earth exploration. vailable at SSRN: http://ssrn.com/abstract=967399.

Flood, S., King, M., Ruggles, S., and Warren, J. R. (2015). Integrated public use microdata series, current population survey: Version 4.0. Minneapolis: University of Minnesota.

Federal Reserve Economic Data -FRED (2016). https://research.stlouisfed.org/fred2 Acessed on May 17, 2016.

Gruber, J. and Hungerman, D. M. (2007). Faith-based charity and crowd-out during the great depression. Journal of Public Economics, 91:1043-1069.

Harbaugh, W. T. (1998). What do donations buy?: A model of philanthropy based on prestige and warm glow. Journal of Public Economics, 67(2):269 - 284.

Information Policy \& Access Center - iPAC (2016)

http://www.plinternetsurvey.org/analysis/public-libraries-and-employment. Acessed on June 10, 2016.

Institute of Museums \& Libraries Services (2013).

http://wwww.imls.gov/sites/default/files/fast_facts_pls_fy2012.pdf. Accessed on September 20, 2015.

James, R. N. (2009). Health, wealth, and charitable estate planning: A longitudinal examination of testamentary charitable giving plans. Nonprofit and Voluntary Sector Quarterly, 38, 10261043.

Katz, S. N. (2006). Philantropy, volume 1 of Handbook of the Economics of Art and Culture, chapter 37, pages 1299-1321. Elsevier.

Kelley, A. (2015). State budget impasse forces library cuts. http://wnep.com/2015/12/08/statebudget-impasse-forces-library-cuts/.

Khanna, J., Posnett, J., and Sandier, T. (1995). Charity donations in the uk: New evidence based on panel data. Journal of Public Economics, 56:257-272.

McCallum, I. and Quinn, S. (2004). Valuing libraries. The Australian Library Journal, 53(1):5569.

Menges, R., Schroeder, C., and Traub, S. (2005). Altruism, warm glow and the willingness-todonate for green electricity: An artefactual field experiment. Environmental and Resource Economics, 31(4):431-458.

Okten, C. and Weisbrod, B. A. (2000). Determinants of donations in private nonprofit markets. Journal of Public Economics, 75:255-272.

Paqué, K.-H. (1982). Do public transfers "crowd out" private charitable giving? some econometric evidence for the federal republic of Germany. Kiel Working Papers, No. 152.

Payne, A. A. (1998). Does the government crowd-out private donations? New evidence from a 
sample of non-profit firms. Journal of Public Economics, 69:323-345.

Peloza, J. and Steel, P. (2005). The price elasticities of charitable contributions: A meta-analysis. Journal of Public Policy \& Marketing, 24(2):260-272.

Reece, W. S. (1979). Charitable contributions: New evidence on household behavior. The American Economic Review, 69(1):142-151.

Simmons, W. O. and Emanuele, R. (2004). Does government spending crowd out donations of time and money? Public Finance Review, 32(5):498-511.

Smith, R. (2015). Cedar rapids library board hears first suggestion on budget cuts. http://www.thegazette.com/subject/news/government/cedar-rapids-library- board-hears-firstsuggestion-on-budget-cuts-20151106.

Smith, T. M. (2003). Raising the barre: The geographic, financial, and economic trends of nonprofit dance companies. Technical report, National Endowment for the Arts. Research Division Report N.44.

Steinberg, R. (1991). Does government spending crowd out donations? Interpreting the evidence. Annals of Public and Cooperative Economics, 62(4):591-612.

Stepleton, I. (2015). Library will keep staff, hours intact despite cuts. http://www.riponpress.com/main.asp?SectionID=2\&SubSectionID=20\&ArticleID=9333.

Warburton, B. (2013). Libraries around the country under budget pressure. http://lj.libraryjournal.com/2013/06/funding/libraries-around-the-country- under-budgetpressure/.

Woods, D. (2015). Bridgeton proposes to close Cumberland county library. http://www.nj.com/cumberland/index.ssf/2015/12/bridgeton_proposes_to_close_cumberland_co unty_libr.html. 


\section{Tables}

Table 1 - Variables description

\begin{tabular}{|c|c|c|}
\hline Variable & Description & Source \\
\hline Donation & Other Revenue Sources (donations, grants and fees) & Public Library Survey \\
\hline Local & Local Government Revenues & Public Library Survey \\
\hline Local2 & Local Government Revenues squared & Created from PLS \\
\hline State & State Government Revenues & Public Library Survey \\
\hline State2 & State Government Revenues squared & Created from PLS \\
\hline Federal & Federal Government Revenues & Public Library Survey \\
\hline Federal2 & Federal Government Revenues squared & Created from PLS \\
\hline Population & Population in Legal Service Area & Public Library Survey \\
\hline Master & Employees with master degree & Public Library Survey \\
\hline Librarian & Librarian employees & Public Library Survey \\
\hline OtherPaid & Other paid employees & Public Library Survey \\
\hline HrsOpen & Number of hours the library was open & Public Library Survey \\
\hline Visits & Number of visits in the library & Public Library Survey \\
\hline KidAttendance & Number of attendance in children programs & Public Library Survey \\
\hline GPTerm & Number of general public terminals with internet connection & Public Library Survey \\
\hline BookVolume & Book volumes & Public Library Survey \\
\hline AudioCol & Audio collection & Public Library Survey \\
\hline VideoCol & Video collection & Public Library Survey \\
\hline Age & Average age in the state & IPUMS-CPS \\
\hline Pincome & Average personal income in state & IPUMS-CPS \\
\hline Female & Percentage of female in state & IPUMS-CPS \\
\hline White & Percentage of white people in state & IPUMS-CPS \\
\hline Black & Percentage of black people in state & IPUMS-CPS \\
\hline Married & Percentage of married couples in state & IPUMS-CPS \\
\hline Immigrant & Percentage of immigrants in state & IPUMS-CPS \\
\hline HighSchool & Percentage of people with high school degree in state & IPUMS-CPS \\
\hline College & Percentage of people with college degree & IPUMS-CPS \\
\hline Unemploy & Percentage of unemployed people & IPUMS-CPS \\
\hline SchDistrict & Dummy variable that equals to 1 if library is run by school district & Created from PLS \\
\hline NonProfit & Dummy variable that equals to 1 if library is run by non-profit & Created from PLS \\
\hline NewEngland & Dummy variable that equals to 1 if it is in New England & Created from PLS \\
\hline Mideast & Dummy variable that equals to 1 if it is in Mideast & Created from PLS \\
\hline GreatLakes & Dummy variable that equals to 1 if it is in Great Lakes & Created from PLS \\
\hline Kap & Dummy variable that equals to 1 if 1 & Created from PLS \\
\hline
\end{tabular}

Source: The author. 
Table 2 - Descriptive Statistics

\begin{tabular}{|c|c|c|c|c|c|}
\hline Variable & $\mathrm{N}$ & Mean & Std Dev & Min & Max \\
\hline Donation & 128,759 & 0.08 & 0.86 & 0.00 & 86.38 \\
\hline Local & 128,759 & 0.77 & 3.32 & 0.00 & 129.82 \\
\hline Local2 & 128,759 & 11.60 & 203.50 & 0.00 & $16,853.77$ \\
\hline State & 128,759 & 0.09 & 0.77 & 0.00 & 53.69 \\
\hline State2 & 128,759 & 0.59 & 21.72 & 0.00 & 2,882.18 \\
\hline Federal & 128,759 & 0.01 & 0.05 & 0.00 & 4.31 \\
\hline Federal2 & 128,759 & 0.00 & 0.11 & 0.00 & 18.59 \\
\hline Population & 128,759 & 0.03 & 0.13 & 0.00 & 4.10 \\
\hline Master & 128,759 & 3.40 & 14.87 & 0.00 & 754.25 \\
\hline Librarian & 128,759 & 5.01 & 16.50 & 0.00 & 754.25 \\
\hline OtherPaid & 128,759 & 10.02 & 40.83 & 0.00 & $2,211.41$ \\
\hline HrsOpen & 128,759 & $3,972.23$ & 8,433.19 & 0.00 & $250,380.00$ \\
\hline Visits & 128,759 & 0.15 & 0.58 & 0.00 & 18.16 \\
\hline KidAttendance & 128,759 & $6,290.64$ & $20,845.86$ & 0.00 & $682,048.00$ \\
\hline GPTerm & 128,759 & 21.68 & 76.81 & 0.00 & $4,123.00$ \\
\hline BookVolume & 128,759 & 86.64 & 358.26 & 0.00 & $22,016.27$ \\
\hline AudioCol & 128,759 & $4,666.87$ & $26,245.21$ & 0.00 & $2,358,459.00$ \\
\hline VideoCol & 128,759 & $4,654.83$ & $17,744.49$ & 0.00 & $796,018.00$ \\
\hline Age & 128,759 & 36.80 & 1.57 & 30.35 & 40.99 \\
\hline Pincome & 128,759 & 17.43 & 2.68 & 11.10 & 27.48 \\
\hline Female & 128,759 & 0.51 & 0.01 & 0.48 & 0.54 \\
\hline White & 128,759 & 0.84 & 0.08 & 0.18 & 0.99 \\
\hline Black & 128,759 & 0.10 & 0.07 & 0.00 & 0.65 \\
\hline Married & 128,759 & 0.42 & 0.02 & 0.22 & 0.49 \\
\hline Immigrant & 128,759 & 0.05 & 0.04 & 0.00 & 0.17 \\
\hline HighSchool & 128,759 & 0.25 & 0.03 & 0.15 & 0.36 \\
\hline College & 128,759 & 0.13 & 0.02 & 0.06 & 0.23 \\
\hline Unemploy & 128,759 & 0.03 & 0.01 & 0.01 & 0.08 \\
\hline SchDistrict & 114,015 & 0.01 & 0.09 & 0.00 & 1.00 \\
\hline NonProfit & 114,015 & 0.16 & 0.37 & 0.00 & 1.00 \\
\hline NewEngland & 128,759 & 0.14 & 0.35 & 0.00 & 1.00 \\
\hline Mideast & 128,759 & 0.17 & 0.38 & 0.00 & 1.00 \\
\hline GreatLakes & 128,759 & 0.21 & 0.40 & 0.00 & 1.00 \\
\hline Kap & 128,759 & 0.45 & 0.50 & 0.00 & 1.00 \\
\hline
\end{tabular}


Table 3 - Outliers libraries ${ }^{\mathrm{a}}$

\begin{tabular}{|c|c|c|c|c|}
\hline ID & State & City & County & Year \\
\hline CA0063 & CA & Los Angeles & Los Angeles & 2004 \\
\hline CA0063 & CA & Los Angeles & Los Angeles & 2005 \\
\hline MD0003 & MD & Baltimore City & Baltimore & 2006 \\
\hline MD0003 & MD & Baltimore City & Baltimore & 2007 \\
\hline MD0003 & MD & Baltimore City & Baltimore & 2008 \\
\hline MD0003 & MD & Baltimore City & Baltimore & 2009 \\
\hline NV0008 & NV & Clark & Las Vegas & 2006 \\
\hline NV0008 & NV & Clark & Las Vegas & 2007 \\
\hline NV0008 & NV & Clark & Las Vegas & 2008 \\
\hline NV0008 & NV & Clark & Las Vegas & 2009 \\
\hline NV0008 & NV & Clark & Las Vegas & 2010 \\
\hline NV0008 & NV & Clark & Las Vegas & 2000 \\
\hline NV0008 & NV & Clark & Las Vegas & 2003 \\
\hline NV0008 & NV & Clark & Las Vegas & 2004 \\
\hline NV0008 & NV & Clark & Las Vegas & 2005 \\
\hline NY0778 & NY & New York & New York & 2000 \\
\hline NY0778 & NY & New York & New York & 2001 \\
\hline NY0778 & NY & New York & New York & 2002 \\
\hline NY0778 & NY & New York & New York & 2003 \\
\hline NY0778 & NY & New York & New York & 2004 \\
\hline NY0778 & NY & New York & New York & 2005 \\
\hline NY0778 & NY & New York & New York & 2006 \\
\hline NY0778 & NY & New York & New York & 2007 \\
\hline NY0778 & NY & New York & New York & 2008 \\
\hline NY0778 & NY & New York & New York & 2009 \\
\hline NY0778 & NY & New York & New York & 2010 \\
\hline NY0778 & NY & New York & New York & 2011 \\
\hline NY0778 & NY & New York & New York & 2012 \\
\hline NY0778 & NY & New York & New York & 2013 \\
\hline OH0057 & $\mathrm{OH}$ & Franklin & Columbus & 2012 \\
\hline
\end{tabular}

Note: ${ }^{a}$ The outlier libraries were those with donations higher than \$1.4 million dollars in real terms

Table 4 - Schedule of report

\begin{tabular}{ccc}
\hline Calendar Year (Jan-Dec) & Fiscal Year (Jul-Jun) & Other Schedule \\
\hline AK AZ CA CT DE GA HI IA & AR CO IN KS LA ME MN ND & MI PA VT NY NH UT AL DC \\
IL KY MA MD MO MT NC & NJ OH TX SD WA WI PW & FL ID MS NE GU MP VI \\
NM NV OK OR RI SC TN VA & & \\
WV WY & & \\
\hline
\end{tabular}


Table 5 - Results ${ }^{\text {a }}$

\begin{tabular}{|c|c|c|c|c|}
\hline & \multicolumn{4}{|c|}{ Dependent Variable: Donation } \\
\hline & \multirow{2}{*}{$\begin{array}{c}\text { POLS } \\
(1)\end{array}$} & \multicolumn{3}{|c|}{$\begin{array}{c}\text { Fixed Effects } \\
\end{array}$} \\
\hline & & $(2)$ & $(3)$ & $(4)$ \\
\hline \multirow[t]{2}{*}{ Local } & $0.028 * * *$ & $0.028 * * *$ & $0.017 * * *$ & 0.002 \\
\hline & $(0.001)$ & $(0.001)$ & $(0.001)$ & $(0.002)$ \\
\hline \multirow[t]{2}{*}{ Local2 } & $-0.0001 * * *$ & $-0.0001 * * *$ & $-0.0001^{* * *}$ & $-0.0001 * * *$ \\
\hline & $(0.00001)$ & $(0.00001)$ & $(0.00001)$ & $(0.00002)$ \\
\hline \multirow[t]{2}{*}{ State } & $0.188 * * *$ & $0.163 * * *$ & $0.210 * * *$ & $-0.066 * * *$ \\
\hline & $(0.002)$ & $(0.002)$ & $(0.002)$ & $(0.004)$ \\
\hline \multirow[t]{2}{*}{ State2 } & $-0.003^{* * *}$ & $-0.003^{* * *}$ & $-0.004^{* * *}$ & $-0.001 * * *$ \\
\hline & $(0.0001)$ & $(0.0001)$ & $(0.0001)$ & $(0.0001)$ \\
\hline \multirow[t]{2}{*}{ Federal } & $0.597 * * *$ & $0.678 * * *$ & $0.899 * * *$ & $0.237 * * *$ \\
\hline & $(0.027)$ & $(0.026)$ & $(0.028)$ & $(0.022)$ \\
\hline \multirow[t]{2}{*}{ Federal2 } & $-0.188 * * *$ & $-0.115^{* * *}$ & $-0.267 * * *$ & $-0.089 * * *$ \\
\hline & $(0.011)$ & $(0.010)$ & $(0.011)$ & $(0.008)$ \\
\hline \multirow[t]{2}{*}{ NewEngland } & $0.014 * * *$ & $0.016 * * *$ & & \\
\hline & $(0.003)$ & $(0.005)$ & & \\
\hline \multirow[t]{2}{*}{ Mideast } & $0.044 * * *$ & $0.019 * * *$ & & \\
\hline & $(0.003)$ & $(0.004)$ & & \\
\hline \multirow[t]{2}{*}{ GreatLakes } & $0.007 * * *$ & $-0.011 * * *$ & & \\
\hline & $(0.002)$ & $(0.003)$ & & \\
\hline Library Control & $\mathrm{X}$ & X & $\mathrm{X}$ & $\mathrm{X}$ \\
\hline State Control & $\mathrm{X}$ & $\mathrm{X}$ & $\mathrm{X}$ & $\mathrm{X}$ \\
\hline County FE & & $\mathrm{X}$ & $\mathrm{X}$ & $\mathrm{X}$ \\
\hline State FE & & & $\mathrm{X}$ & $\mathrm{X}$ \\
\hline Library FE & & & & $\mathrm{X}$ \\
\hline Year FE & & $X$ & $\mathrm{X}$ & $\mathrm{X}$ \\
\hline Observations & 113,993 & 113,993 & 113,993 & 113,993 \\
\hline $\mathrm{R}^{2}$ & 0.587 & 0.704 & 0.603 & 0.861 \\
\hline Adjusted $\mathrm{R}^{2}$ & 0.587 & 0.699 & 0.603 & 0.845 \\
\hline
\end{tabular}

Notes: ${ }^{*} \mathrm{p}<0.1 ;{ }^{* *} \mathrm{p}<0.05 ;{ }^{* * *} \mathrm{p}<0.01$. Library Control: Population, Master, Librarian, OtherPaid, HrsOpen, Visits, BookVolume, AudioCol, VideoCol, GPTerm, KidAttendance, Report1, Kap, SchDistrict, NonProfit. State Control:

Pincome, Age, Female, White, Black, Married, Immigrant, HighSchool, College, Unemploy. 
Table 6 -Tobit results ${ }^{\mathrm{a}}$

\begin{tabular}{lllll}
\hline & \multicolumn{4}{c}{ Dependent Variable: Donation } \\
\cline { 2 - 5 } & \multicolumn{1}{c}{$(1)$} & \multicolumn{1}{c}{$(2)$} & \multicolumn{1}{c}{$(3)$} & \multicolumn{1}{c}{$(4)$} \\
\hline Local & $0.063^{* * *}$ & $0.017^{* * *}$ & $0.014^{* * *}$ & $0.062^{* * *}$ \\
Local2 & $(0.0004)$ & $(0.001)$ & $(0.001)$ & $(0.0004)$ \\
& $-0.0003^{* * *}$ & $-0.0001^{* * *}$ & $-0.0001^{* * *}$ & $-0.0003^{* * *}$ \\
State & $(0.00001)$ & $(0.00001)$ & $(0.00001)$ & $(0.00001)$ \\
& $0.208^{* * *}$ & $0.150^{* * *}$ & $0.149^{* * *}$ & $0.229^{* * *}$ \\
State2 & $(0.002)$ & $(0.002)$ & $(0.002)$ & $(0.002)$ \\
& $-0.003^{* * *}$ & $-0.003^{* * *}$ & $-0.003^{* * *}$ & $-0.003^{* * *}$ \\
Federal & $(0.0001)$ & $(0.0001)$ & $(0.0001)$ & $(0.0001)$ \\
& $1.024^{* * *}$ & $0.677^{* * *}$ & $0.674^{* * *}$ & $1.326^{* * *}$ \\
Federal2 & $(0.026)$ & $(0.027)$ & $(0.027)$ & $(0.027)$ \\
& $-0.232^{* * *}$ & $-0.202^{* * *}$ & $-0.204^{* * *}$ & $-0.311^{* * *}$ \\
logSigma & $(0.011)$ & $(0.011)$ & $(0.011)$ & $(0.011)$ \\
& $-1.534^{* * *}$ & $-1.553^{* * *}$ & $-1.554^{* * *}$ & $-1.557^{* * *}$ \\
\hline Library Control & $(0.002)$ & $(0.002)$ & $(0.002)$ & $(0.002)$ \\
State Control & & $\mathrm{X}$ & $\mathrm{X}$ & \\
County FE & & $\mathrm{X}$ & $\mathrm{X}$ & \\
State FE & & & & \\
Library FE & & & & $\mathrm{X}$ \\
Year FE & & & & $\mathrm{X}$ \\
\hline Observations & 128,729 & 128,729 & 128,729 & 128,729 \\
Log Likelihood & $5,320.25$ & $7,766.52$ & $7,954.51$ & $8,593.74$ \\
Akaike Inf. Crit. & $-10,624.51$ & $-15,501.04$ & $-15,863.02$ & $-17,045.48$ \\
Bayesian Inf. Crit. & $-10,546.38$ & $-15,344.79$ & $-15,638.41$ & $-16,352.13$ \\
\hline
\end{tabular}

Notes: ${ }^{a} \mathrm{p}<0.1 ;{ }^{* *} \mathrm{p}<0.05 ;{ }^{* * *} \mathrm{p}<0.01$. Library Control: in (2) - Population, TotalStaff, Visits, BookVolume; in (3) (2) plus GPTerm, Kap. State Control: in (2) - Pincome, Female, White, Age; in (3) - (2) plus Married, Immigrant, HighSchool, College, Unemploy. 
Table 7 - Robustness Check 1: per capita values ${ }^{\mathrm{a}}$

\begin{tabular}{lllll}
\hline & \multicolumn{3}{c}{ Dependent Variable: Donation per capita } \\
\cline { 2 - 5 } & \multicolumn{1}{c}{ POLS } & \multicolumn{3}{c}{ Fixed Effects } \\
\cline { 2 - 5 } & \multicolumn{1}{c}{$(1)$} & \multicolumn{1}{c}{$(2)$} & \multicolumn{1}{c}{$(3)$} & $(4)$ \\
\hline Local & $0.019^{* * *}$ & $0.021^{* * *}$ & $0.015^{* * *}$ & $0.019^{* * *}$ \\
& $(0.001)$ & $(0.002)$ & $(0.001)$ & $(0.002)$ \\
Local2 & $-0.001^{* * *}$ & $-0.001^{* * *}$ & $-0.001^{* * *}$ & $-0.001^{* * *}$ \\
& $(0.0001)$ & $(0.0001)$ & $(0.0001)$ & $(0.0001)$ \\
State & $0.086^{* * *}$ & $0.100^{* * *}$ & $0.192^{* * *}$ & $0.033^{* *}$ \\
& $(0.008)$ & $(0.009)$ & $(0.012)$ & $(0.013)$ \\
State2 & $0.941^{* * *}$ & $0.878^{* * *}$ & $0.651^{* * *}$ & $1.172^{* * *}$ \\
& $(0.036)$ & $(0.039)$ & $(0.043)$ & $(0.048)$ \\
Federal & $0.743^{* * *}$ & $0.894^{* * *}$ & $0.718^{* * *}$ & $1.251^{* * *}$ \\
& $(0.008)$ & $(0.009)$ & $(0.008)$ & $(0.009)$ \\
Federal2 & $-0.270^{* * *}$ & $-0.320^{* * *}$ & $-0.260^{* * *}$ & $-0.470^{* * *}$ \\
& $(0.004)$ & $(0.004)$ & $(0.004)$ & $(0.004)$ \\
NewEngland & $0.003^{* * *}$ & $0.008^{* * *}$ & & \\
& $(0.0002)$ & $(0.0004)$ & & \\
Mideast & $0.004^{* * *}$ & $0.004^{* * *}$ & & \\
& $(0.0002)$ & $(0.0004)$ & & \\
GreatLakes & $0.001^{* * *}$ & 0.0001 & & \\
& $(0.0002)$ & $(0.0002)$ & & \\
\hline Library Control & $\mathrm{X}$ & $\mathrm{X}$ & $\mathrm{X}$ & $\mathrm{X}$ \\
State Control & $\mathrm{X}$ & $\mathrm{X}$ & $\mathrm{X}$ & $\mathrm{X}$ \\
County FE & & $\mathrm{X}$ & & $\mathrm{X}$ \\
State FE & & & $\mathrm{X}$ & $\mathrm{X}$ \\
Library FE & & & & $\mathrm{X}$ \\
Year FE & & $\mathrm{X}$ & $\mathrm{X}$ & $\mathrm{X}$ \\
\hline Observations & 128,729 & 128,729 & 128,729 & 128,729 \\
R2 & 0.106 & 0.167 & 0.117 & 0.555 \\
Adjusted R2 & 0.106 & 0.155 & 0.117 & 0.511 \\
\hline & & & & \\
\hline
\end{tabular}

Notes: ${ }^{a}{ }^{*} \mathrm{p}<0.1 ;{ }^{* *} \mathrm{p}<0.05 ;{ }^{* * *} \mathrm{p}<0.01$. Library Control: Population, Master, Librarian, OtherPaid, HrsOpen, Visits, BookVolume, AudioCol, VideoCol, GPTerm, KidAttendance, Report1, Kap. State Control: Pincome, Age, Female, White, Black, Married, Immigrant, HighSchool, College, Unemploy.

Table 8 - Robustness Check 2: Tobit in per capita values ${ }^{\mathrm{a}}$ 


\begin{tabular}{|c|c|c|}
\hline & \multicolumn{2}{|c|}{ Dependent Variable: Donation per capita } \\
\hline & $(1)$ & $(2)$ \\
\hline \multirow[t]{2}{*}{ Local } & $0.048 * * *$ & $0.042 * * *$ \\
\hline & $(0.002)$ & $(0.002)$ \\
\hline \multirow[t]{2}{*}{ Local2 } & $-0.037 * * *$ & $-0.037 * * *$ \\
\hline & $(0.002)$ & $(0.003)$ \\
\hline \multirow[t]{2}{*}{ State } & $0.091 * * *$ & $0.205^{* * *}$ \\
\hline & $(0.008)$ & $(0.012)$ \\
\hline \multirow[t]{2}{*}{ State2 } & $0.954 * * *$ & $0.665 * * *$ \\
\hline & $(0.038)$ & $(0.045)$ \\
\hline \multirow[t]{2}{*}{ Federal } & $0.724 * * *$ & $0.726 * * *$ \\
\hline & $(0.009)$ & $(0.009)$ \\
\hline \multirow[t]{2}{*}{ Federal2 } & $-0.263 * * *$ & $-0.264 * * *$ \\
\hline & $(0.004)$ & $(0.004)$ \\
\hline \multirow[t]{2}{*}{ logSigma } & $-4.060 * * *$ & $-4.073 * * *$ \\
\hline & $(0.002)$ & $(0.002)$ \\
\hline \multicolumn{3}{|l|}{ Library Control } \\
\hline \multicolumn{3}{|l|}{ State Control } \\
\hline \multicolumn{3}{|l|}{ County FE } \\
\hline State FE & & $\mathrm{X}$ \\
\hline \multicolumn{3}{|l|}{ Library FE } \\
\hline Year FE & & $\mathrm{X}$ \\
\hline Observations & 128,729 & 128,729 \\
\hline Log Likelihood & 301117.9 & 303127.6 \\
\hline Akaike Inf. Crit. & -602219.9 & -606113.2 \\
\hline Bayesian Inf. Crit. & -602141.8 & -605419.9 \\
\hline
\end{tabular}

Notes: ${ }^{\text {a }} \mathrm{p}<0.1 ;{ }^{* *} \mathrm{p}<0.05 ;{ }^{* * *} \mathrm{p}<0.01$

Table 9 - Robustness Check 3: Outliers ${ }^{\mathrm{a}}$ 


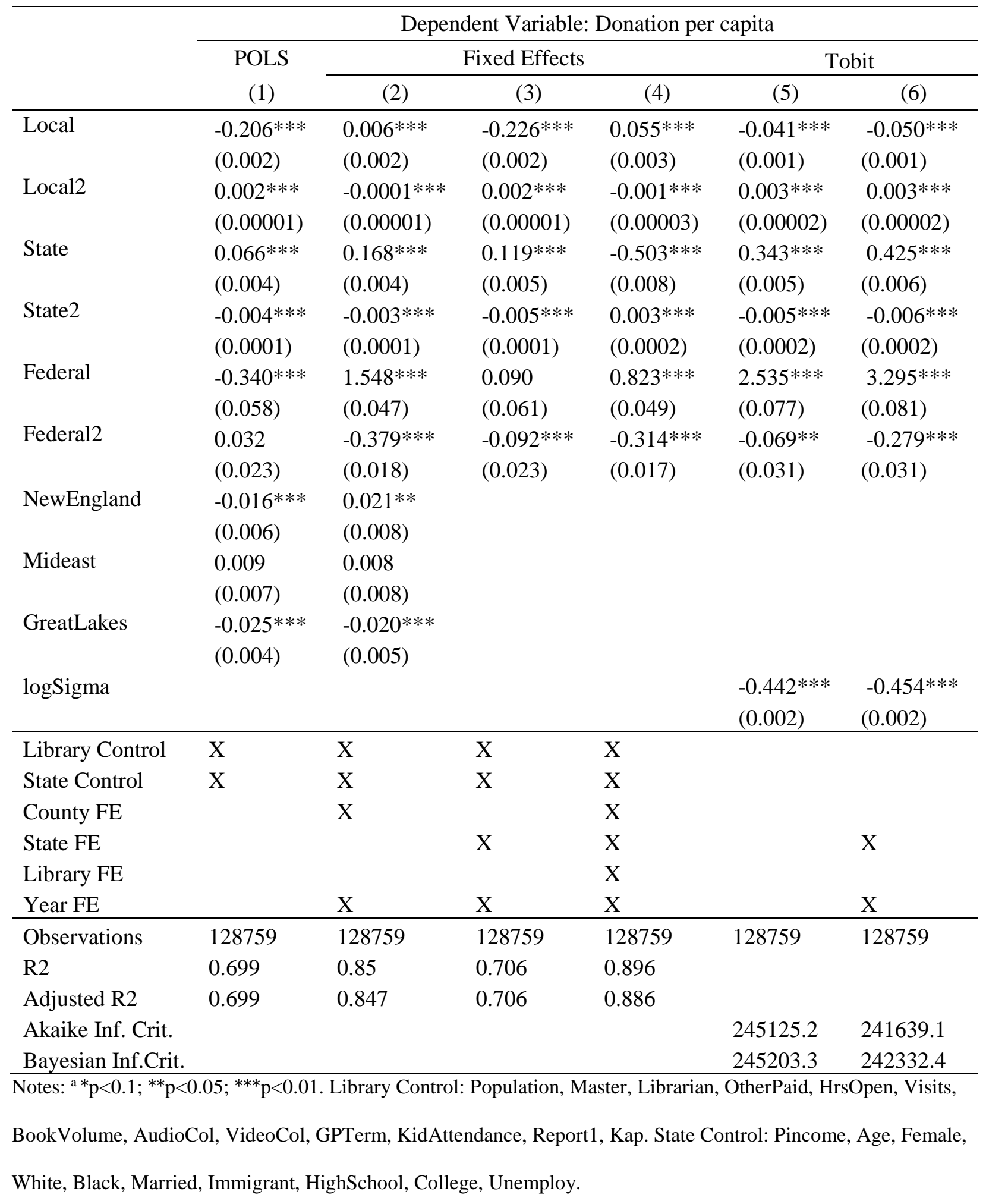

Figure 1 - Scatterplot of Government Expenditure vs. Donation 

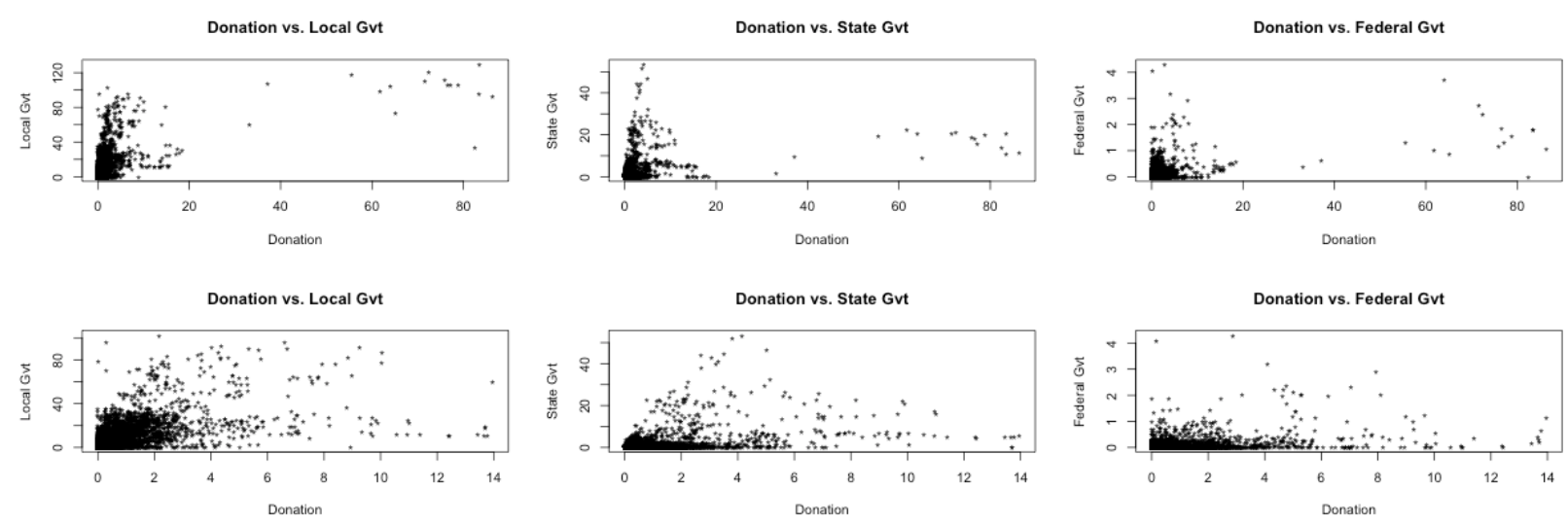